\title{
Reorientation of Javanese Beginning Reading Learning Models on the Grade 1 Student of Elementary School
}

\author{
Astiana Ajeng Rahadini ${ }^{1,2 *}$, Endang Nurhayati ${ }^{1}$, Suwarna Suwarna ${ }^{1}$ \\ ${ }^{1}$ Postgraduate School, Universitas Negeri Yogyakarta, Indonesia \\ ${ }^{2}$ Sebelas Maret University, Surakarta, Indonesia
}

Received March 2, 2020; Revised April 22, 2020; Accepted April 29, 2020

Copyright $@ 2020$ by authors, all rights reserved. Authors agree that this article remains permanently open access under the terms of the Creative Commons Attribution License 4.0 International License

\begin{abstract}
Reading has an important role in life. In Indonesia, beginning reading is introduced from the first grade in elementary schools, including learning of Javanese. Unfortunately, many Javanese children are increasingly strange to the language. Therefore, the learning model chosen must be appropriate. Based on the results of research on schools in the ex-residency area of Surakarta, the most widely use of learning models is spelling with very limited textbooks. The teacher's orientation is only to make students read regardless of whether students' interest in reading grows or not. This is unfortunate because of the important role of motivation to learning outcomes. Therefore, it is very necessary for teachers to pay attention to other factors such as children's learning motivation, appropriate children's reading materials, and other factors so that orientation of Javanese beginning reading not only produces children who can read but also like to read.
\end{abstract}

Keywords Beginning Reading, Reading Learning Orientation, Javanese Language Learning, Learning Model, Grade 1, Elementary School

\section{Introduction}

Reading has an important role in life. Someone will easily access information from books and other reading materials if they have reading skills. Reading activities are the focus of this research because reading is a "bridge" to gain knowledge. Iskandarwassid \& Sunendar [1]state that the highest percentage of knowledge transfer is done through reading activities. Reading is also the main activity of literacy which was declared as the main agenda of global community development in 2015 by the United Nations with the term "Decade of Literacy". This agenda suggests that in the decade of that year all citizens of the world must be free from illiteration [2].

To realize this mission, reading activities are introduced to children from an early age.Grade levels in primary schools in Indonesia consist of six classes ranging from grades I, II, III, Iv, V, and VI. The level of this class can be divided into two, namely low class and high class. Low class consists of classes one, two, and three while high class consists of classes four, five, and six. Primary low class students are in the age range of 7 to 9 years.Learning to read in Indonesia is formally taught since grade $\mathrm{I}$ in primary schools based on Permendikbud Number 24/2016 which contains pre-reading activities. According to Musfiroh and Listyorini [3], reading in grades I through grade III in elementary school is included in the concept of learning to learn to read. At this stage, the main focus is to teach beginning reading techniques to children so that children can have a solid reading ability so that later reading stages can be mastered well. This stage should be known by the teacher and the school so that they can guide, teach and facilitate students in grades I, II, and III of elementary school by learning to read that is appropriate to the reading concepts possessed by children. The school age of primary school children in Indonesia is in the 7-12 year age range or at least primary school when they are 6 years old on July 1 of the current year with a recommendation from a Psychologist [4]. In accordance with Piaget's concept of cognitive development [5], children between 5-7.5 years or grade I are at a concrete operational stage and are generally more likely to work individually. The cooperative learning model is not suitable for teaching children. Concrete operational stage means that children focus more on things that are concrete, especially for early age at that stage. Concrete in this case means actual or in accordance with events that exist in a real situation.

Distinctive characteristics of early elementary school children should be understood correctly by the teacher so that it is appropriate in choosing the methods and learning materials for children. Nurgiyantoro [6] explains the 
characteristics of reading books that are appropriate for children of this age, which include 1) narrative reading books or explanations that contain a logical sequence from simple to more complex, 2) reading books that display simple stories both concerning problems narrated, how to tell, as well as the number of characters involved, 3) reading books that display a variety of object images that may vary even in the form of diagrams or simple models, 4) narrative reading books that feature narrators that tell stories or stories that can bring children to projecting itself to another time or place. At this age children can also be involved in thinking about the problems faced by the protagonist and thinking about the continuation of the story.

No less important, the thing that must be considered is the language used in reading. Reading is one part of language development experienced by children. Of course the language most mastered by children is the first language taught and used in daily interactions at home. But unfortunately in this era, many young Javanese families do not use Javanese as their first language, so many children are unfamiliar with Javanese. Even in the Tribune Jogja Newspaper on February 28, 2018 it was mentioned that many residents of Yogyakarta consider Javanese language complicated so many parents prefer Indonesian as the language of daily communication. This is also supported by Setyawan's research [7]which shows that the mastery of Javanese among young people is decreasing because they are not accustomed to using it in daily communication.

Javanese is the regional language with the largest number of speakers in Indonesia, which is around 68.2 million people. In addition, Javanese as a regional language has its function and position set in the 1945 Constitution as a supporting element of Indonesian language whose existence is guaranteed and protected by the government. Regional languages are also used as a means to preserve and develop culture. Javanese has unique phonemes and words that are different from other languages. Therefore, learning to read Javanese should be given special attention early on so that children can read reading materials in Javanese. There are various kinds of Javanese literary works that contain teachings of moral values which should be passed down from generation to generation as Javanese way of life. If not, then the Javanese children will be increasingly foreign to the language so that gradually the Javanese language will not develop and become extinct, including the valuable literary works.

Based on this, it is very important for teachers to implement appropriate reading learning models for children. Learning models means an instructional framework that consists of guide to teach students, learning materials, and how to evaluate it. Learning models consist of five components such as syntax, social system, the principle of reaction, support system, and the last is teaching and follow-up impact. So, the reading learning models is an instructional framework that consists of guide to teach read. The NAEYC (National Association for Education of Young Children) provides recommendations for teaching reading models for children recognizing single letters, reading the alphabet, and singing alphabet songs[8]. Meanwhile, according to Akhadiah [9], learning models that can be used to teach beginning reading are learning models of spelling, Structural-Analytic-Synthesis or SAS, said institutions, and learning models with pictorial card media. All learning models are selected by adjusting the situation and characteristics of students. Each learning model has advantages and disadvantages. This study aims to determine the model of beginning reading learning that is implemented in public and private elementary schools and the orientation that teachers want to achieve by choosing the learning model used.

\section{Method}

This research is a type of qualitative research that aims to describe the implementation of the initial reading learning model in low grade primary schools in the ex-residency area of Surakarta and the orientation of the implementation of reading learning. The former ex-residency area of Surakarta consists of Surakarta City, Sukoharjo District, Boyolali District, Wonogiri District, Klaten District, and Karanganyar District. The population in this study is all public and private elementary schools in the ex-residency area of Surakarta. The sample of this research is 12 primary schools in 6 districts, which consist of 6 public primary schools and 6 private primary schools randomly selected. Data collection methods are by observation, interview, and document analysis. Observation is used to observe the implementation of the model of learning to begin with in the sample schools. Interviews are used to ask in more detail about the orientation and reasons for choosing the model of learning to begin with, and document analysis is used to determine the sequence of learning that has been planned in writing. The ten schools that were sampled for this study are in the following table:

Table 1. List of Research School Samples

\begin{tabular}{|c|c|c|}
\hline No & District & School name \\
\hline 1. & Surakarta & SD N Mipitan No 168 Surakarta \\
\hline & & MI UQ Ali Bin Abi Thalib \\
\hline 2. & Sukoharjo & SD Negeri 01 Gayam \\
\hline & & MI Bendungan \\
\hline 3. & Boyolali & SD N 03 Boyolali \\
\hline & & SD Muhammadiyah \\
\hline 4. & Wonogiri & SD N 04 Wuryantoro \\
\hline & & SD Muhammadiyah 1 Wonogiri \\
\hline 5. & Klaten & SD Negeri 1 Karangdowo \\
\hline & & SD Muhammadiyah Klaten Utara \\
\hline 6. & Karanganyar & SD N 03 Jaten \\
\hline & & SD Islam Al-Hadi \\
\hline
\end{tabular}




\section{Finding and Discussion}

\subsection{Finding}

The learning model used by teachers in learning to beginning reading in low grade elementary school students in the ex-residency area of Surakarta is spelling. More detailed data about the learning model used is in the following table.

Table 2. The use of beginning reading learning models

\begin{tabular}{|c|c|c|c|}
\hline No & District & School name & $\begin{array}{c}\text { Learning } \\
\text { Model used }\end{array}$ \\
\hline 1. & Surakarta & $\begin{array}{c}\text { SD N Mipitan No 168 } \\
\text { Surakarta }\end{array}$ & Spell \\
\hline & & $\begin{array}{c}\text { MI UQ Ali Bin Abi } \\
\text { Thalib }\end{array}$ & Spell \\
\hline 2. & Sukoharjo & Sd Negeri 01 Gayam & Spell \\
\hline 3. & Boyolali & MI Bendungan & Spell \\
\hline 4. & Wonogiri 03 Boyolali & Spell \\
\hline & & SD Muhammadiyah & Spell \\
\hline 5. & Klaten & $\begin{array}{c}\text { SD Muhammadiyah 1 } \\
\text { Wonogiri }\end{array}$ & Spell \\
\hline & & $\begin{array}{c}\text { SD Muhammadiyah } \\
\text { Klaten Utara }\end{array}$ & Spell \\
\hline 6. & Karanganyar & SD N 03 Jaten & Spell \\
\hline & & SD Islam Al-Hadi & Spell \\
\hline
\end{tabular}

Based on the results of the interviews, the two models were applied without any special reason. The teacher's aim is "what is important is that the child is young and can read." The following components of the beginning reading model of spelling are obtained based on the results of the study.

\section{a. Syntax}

1. The syntax of the spelling reading learning model, namely.

2. The teacher enters the class, then says hello and prays.

3. The teacher gives an introduction to learning to read to children.

4. The teacher introduces letters one by one by writing one capital letter on the board followed by 5 lowercase letters, then reciting them. Starting from A-a to Z-z. The new teacher switches when the children are able to follow.

Teacher : “Ayo digatekke ibu nulis huruf ing papan tulis. Sing ibu tulis iki /A/ diwaca Students : “A..."

Then the teacher recites the letters in the next line to the fifth line.
Teacher : "A..."

Student : "A...”

Teacher : : "Ya pinter. Saiki dibacutke karo huruf sing keloro yaiku huruf B”

The teacher then writes the letter B as much as 5 lines then gives an example of how to read it and is followed by the children.

Teacher : "Ya saiki nirokke ibu guru ya, iki diwaca Be..”

Student : "Be..."

5. Within a day children are taught 10 letters

The way to spell the alphabet by the teacher is: /a/, /be/,/ce/, /de/, /e/, /ef/, /ge/, /ha/, /i/, /je/, /ka/, /el/, /em/, /en, /o/, /pe/, /qi/, /er/, /es/, /te/, /u/, /ve/, /we/, /x/, /ye/, /zet/

6. After the third day, the teacher starts arranging letters into syllables by attaching consonants with vowels and teaching them to read using the spelling reading model.

The teacher writes BA BI BU BE BO.

Teachers : "Ayo coba digatekke maneh tulisan huruf-huruf ing papan tulis iki. Iki rong huruf ibu dadekke siji. Sing pisanan. /Be/-/A/ diwaca BA. Coba ditirokke.

Student : "Be-A..BA."

7. The teacher continues to write examples of syllables from familiar letters to form words that sound.

Example: letters B, A, D, U become B-A $\rightarrow$ BA (read or spelled / be-a / [ba]

$\mathrm{D}-\mathrm{U} \rightarrow \mathrm{DU}$ (read or spelled / de-u / $\diamond[\mathrm{du}]$

8. After understanding how to read words, the next step is the teacher teaches how to read short or simple sentences by arranging simple words that are easy to read.

The thing that gets emphasis in learning to spell Javanese language is on typical Javanese phonemes such as [dh], [d], [th], and [t] phonemes. besides the vowels in the form of allophones such as [o], [U], [I], [ع]

\section{b. Social system}

To reduce boredom and boredom of students, teachers sometimes insert songs or games in the middle of the learning process.

Example:

Teacher : "A-Be-Ce-De-E-Ef-Ge-Ha-I-Je-Ka-ElEm-En-O-Pe-Qi-Er-Es-Te-U-Ve-We-Ix$Y e-Z e$. Ayo nyanyi bebarengan karo ibu ya."

The children imitated the song sung by the teacher.

\section{c. The principle of reaction}

The interactions that arise in learning to read spelling 
and connecting do not allow students to ask questions because the teacher dominates learning. However, teachers often give appreciation for students' abilities, such as the following example:

Teacher : "Ya pinter..."

The speech is given by the teacher when the teacher gives an example of reciting letters and students can imitate well, especially when non-repetitive examples are presented, students can answer the letters correctly.

Teacher : "Iya betul..saiki wis padha pinter maca ya.."

This is often said by the teacher at the end of the stage (single letter reading, syllable, word) when students can read correctly.

\section{d. Support system}

Supporting facilities used for learning are Javanese language textbooks and student worksheets. The textbooks used included: Wasis Bases, I Can Basa, and Pinter Basa. During the interview to find out the teacher's opinion about the quality of the book used, ten interviewees said that the book used had a load that was too high or difficult to accept for elementary school children. There is one school that uses pictorial card media, namely SD N 04 Wuryantoro Wonogiri

\section{e. Teaching and follow-up impacts:}

The impact of teaching from the application of the spelling reading model is that students become memorized alphabetically. Meanwhile the follow-up effect of implementing the spelling reading model is that students can read.

\section{Discussion}

Judging from the implementation of the beginning of reading learning in various elementary schools in the former residency of Surakarta, the dominant learning model used by paraguru is the spelling learning model. The spelling learning model has the main goal of making students can read.

This goal seems to be the only goal of learning to read. Though there are other factors that also play a role in improving reading skills, namely reading interest. Spelling skills are not related to reading skills [10]. Children who have poor spelling skills may not necessarily have low reading skills.

Utomo [11]states that motivation is the most dominant factor in determining learning outcomes, including learning to read. Learning motivation is a factor that underlies a learner who has the desire, interest, encouragement, and awareness to carry out various learning activities so that learning outcomes can be improved. The teacher should not only be oriented towards cognitive abilities but also the motivation of learning possessed by students, including in learning to read.

Based on the characteristics of elementary school students grade I which is a period of transition from playing to learning formally, one of the efforts that can be used to increase motivation to learn is not to abandon aspects of play or physical involvement in learning activities. Some teachers in the sample schools have implemented it with the aim that students do not get bored in monotonous spelling activities. One of the learning models that has proven to be effective in the language learning process of first grade students in elementary schools is TPR (Total Physical Response) [12]. The TPR learning model involves a variety of physical activities in teaching various vocabulary to elementary school children in grade 1. Students look happy and enthusiastic when following vocabulary learning with instructions that ask them to move and not just sit and learn to read. The feeling of pleasure makes them not feel bored when learning takes place so that knowledge is more easily accepted.

Another interesting learning model for children is storytelling [13]. Storytelling is one of the learning activities used in learning vocabulary and developing children's literacy. The teacher draws the child's attention through speech, pauses, expressions, and prosody. This makes children interested and involved in the story so that love for literacy develops.

Based on the research of Schaars \& Verhoeven [14]other factors that determine children's reading abilities are in addition to the methods used to learn to read, namely phonological awareness, mastered vocabulary, word decoding skills, and short-term memory skills.

The habit of reading is indeed not able to grow instantly but it must be familiarized. Based on a UNESCO survey in 2011 the index level of interest in reading Indonesian people was only $0.001 \%[15]$. This means, in Indonesia only 1 in 1000 people in Indonesia reads books seriously. Silinkas \& Nurmi [16]state that there is a positive relationship between reading activities of parents at home with reading skills of kindergarten and elementary school children. Therefore, one's reading ability is arguably not only a product of reading learning but also a habit that is cultivated in the family environment through parental participation. Children are accomplished imitators, including imitating the reading habits of parents. Parents who like to read will also pay more attention to the availability of reading material at home so that children have more learning resources to read.

In Indonesia, efforts to formally develop a love for reading have been initiated by the government through the Minister of Education and Culture Regulation No. 23 of 2015, one of which is through the School Literacy Movement (GLS). But apparently the implementation of the School Literacy Movement was not carried out routinely in schools [17]. Based on this research around 
$40 \%$ of schools do not regularly schedule school literacy activities. Some problems that arise include the lack of reading material for elementary school students.

Based on research data, Javanese language learning is also very dependent on the textbooks used by the teacher. In fact, the teacher himself realized that the material contained in the book was too heavy and not suitable. Some schools even use LKS as teaching material. Based on Chang's research results [18]the use of these worksheets is not in accordance with the advice of experts related to language learning materials for children who should be active and interactive.

Language learning for low grade elementary school children should be emphasized on language learning materials that are meaningful, interesting, and in accordance with daily activities. This is in accordance with the principle of developing good teaching materials for children proposed by Tomlinson [19]who states that the language discourse features available for potential acquisition need to be salient, meaningful, and frequently encountered. The statement shows that teachers need to present material in the form of contexts that are truly experienced by children in real life so that they are reachable by their cognitive. This concept is in line with meaningful learning or meaningful learning formulated by Ausubel [20]. Children will be more able to construct the knowledge provided if they can feel the benefits and use the knowledge directly in the real world.

Meanwhile, the interesting aspects can be highlighted by focusing on the textbook illustrations. Based on the results of Utomo's research [11], illustrated textbooks are appropriate for primary school students in grade I because they can improve reading skills and increase student motivation. The illustrations that are presented can make a child imagine, associating with the knowledge he has so that he can predict what words are appropriate for the illustrations

\section{Conclusions}

Judging from the syntax of learning, the learning model of spelling and pictorial words applied has a short-term learning goal or orientation, ie students can read. The long-term impact is that students become fond of reading as if they are considered not important or not made as one of the significant orientations. Reading fondness shows the existence of intrinsic motivation that can encourage children to continue reading and continue to improve their reading abilities.

The textbooks used also have an influence in improving reading skills so teachers must consider the selection of textbooks. Even better, the teacher himself develops the teaching material because the teacher is the one who best knows the state of the student.

These two things must be thought out and sought solutions through further research so that reading culture is not only a discourse but truly realized. The model of reading learning that is applied should also prioritize the realization of a culture of fond of reading so that illiteration in Indonesia can be eliminated and the level of reading ability of Indonesian children can continue to increase.

\section{REFERENCES}

[1] Iskandarwassid and D. Sunendar, "Strategi Pembelajaran Bahasa," 2011.

[2] D. R. Olson and N. Torrance, The Cambridge handbook of literacy. Cambridge University Press, 2009.

[3] T. Musfiroh and B. Listyorini, "Konstruk kompetensi literasi untuk siswa sekolah dasar," Litera, vol. 15, no. 1, 2016.

[4] Minister of National Education, Permendiknas No.2/2008. Jakarta: Department of National Education., 2008.

[5] J. Piaget, "The language and thought of the child (M. Gabain, Trans.),” New York, 1959.

[6] B. Nurgiyantoro, “Tahapan Perkembangan Anak dan Pemilihan Bacaan Sastra Anak" dalam Cakrawala Pendidikan.” Juni Tahun, 2005.

[7] B. W. Setyawan, "Fenomena Penggunaan Unggah-Ungguh Basa Jawa Kalangan Siswa SMK di Surakarta (Phenomenom of the Using Unggah-Ungguh Basa Jawa of Vocational High School Student in Surakarta)," Widyaparwa, vol. 46, no. 2, pp. 145-156, 2018.

[8] J. W. Santrock, "Life span development: Perkembangan masa hidup,” Jakarta: Erlangga, vol. 31, 2002.

[9] S. Akhadiah, "Membaca sebagai Keterampilan Dasar," Jakarta: Depdikbud, 1991.

[10] M. Gangl, K. Moll, C. Banfi, S. Huber, G. Schulte-Körne, and K. Landerl, "Reading strategies of good and poor readers of German with different spelling abilities,” J. Exp. Child Psychol., vol. 174, pp. 150-169, 2018.

[11] F. B. B. Utomo, "Developing illustrated story books to improve beginning reading skills and learning motivation," J. Prima Edukasia, vol. 6, no. 2, pp. 118-128, 2018.

[12] I. Sariyati, “The effectiveness of TPR (Total Physical Response) method in English vocabulary mastery of elementary school children,” Parol. J. Linguist. Educ., vol. 3, no. 1 April, pp. 50-64, 2013.

[13] A. Cekaite and P. Björk-Willén, "Enchantment in storytelling: co-operation and participation in children's aesthetic experience,” Linguist. Educ., vol. 48, pp. 52-60, 2018.

[14] M. M. H. Schaars, E. Segers, and L. Verhoeven, "Cognitive and linguistic precursors of early first and second language reading development," Learn. Individ. Differ., vol. 72, pp. 1-14, 2019. 
[15] D. Susila, "Menumbuhkan Minat Baca dari Daerah," Koran Sindo, 2016.

[16] G. Silinskas, M.-K. Lerkkanen, A. Tolvanen, P. Niemi, A.-M. Poikkeus, and J.-E. Nurmi, "The frequency of parents' reading-related activities at home and children's reading skills during kindergarten and Grade 1,” J. Appl. Dev. Psychol., vol. 33, no. 6, pp. 302-310, 2012.

[17] N. Nurkaeti, S. Aryanto, and Y. Gumala, "READ ALOUD: A LITERACY ACTIVITY IN ELEMENTARY SCHOOL," PrimaryEdu-Journal Prim. Educ., vol. 3, no. 2, pp. 55-61, 2019.

[18] G.-J. Hwang, S.-C. Chang, P.-Y. Chen, and X.-Y. Chen, "Effects of Integrating an Active Learning-Promoting Mechanism into Location-based Real-World Learning Environments on Students' Learning Performances and Behaviors,” Educ. Technol. Res. Dev., vol. 66, no. 2, pp. 451-474, 2018.

[19] $\mathrm{B}$. Tomlinson and H. Masuhara, The complete guide to the theory and practice of materials development for language learning. John Wiley \& Sons, 2017.

[20] D. P. Ausubel, "The facilitation of meaningful verbal learning in the classroom,” Educ. Psychol., vol. 12, no. 2, pp. 162-178, 1977. 